\title{
When Prior Knowledge Helps: Self-Report of First-Year University Undergraduates on Academic Writing
}

\author{
Uju C. Ukwuoma \\ Botswana International University of Science and Technology (BIUST), Palapye, Botswana
}

\begin{abstract}
This qualitative-dominant mixed study used content analysis, interviews, and survey to examine if first-year university undergraduates taking English language academic writing courses consider prior knowledge from high school English language five-paragraph essay writing style helpful. Sample included 67 first year university undergraduates. All the 67 students considered prior knowledge of the high school five-paragraph essay writing style helpful. They believed that it facilitated a transfer of learning in the first-year university undergraduate academic writing course. However, only 15 out of the respondents, who reported that prior knowledge of the high school English language five-paragraph essay writing style was helpful, also reported that they are level-appropriate competent in the first-year university undergraduate English language academic writing courses after one academic year. As such, essay-writing in high school offers students some foundation-knowledge to succeed in academic writing in universities. Further findings showed that students often delve into essay or academic writing without proper planning. Thus, it is recommended that universities introduce a bridge course specifically to address academic deficiency in reading and writing for all first year undergraduates upon admission into the university.
\end{abstract}

Keywords: academic writing, first-year university students, essay writing, five-paragraph style

Writing is perceived as a challenging field to measure (Munoz-Luna, 2013; Nelson \& Calfee, 1998), yet schools are using writing to measure the progress of their students in various fields due to the importance attached to writing (Blaxter, Hughes, \& Tight, 1998; Cramarenco, Moraru, Balazsi, \& Aluas, 2015; Walker, Golde, Jones, Conklin, Bueschelp, \& Hutchings, 2008). Thus, several studies have established the need for students to receive appropriate instruction on how to write (Chovance, 2012; Curry \& Hewings, 2003; Jabulani, 2014; Kern \& Schultz, 2005; Poel \& Gasiorek, 2012). Accordingly, high school essay is expected to prepare students for the academic writing they will encounter in university education. Nevertheless, researchers have documented the existence of enormous evidence showing that majority of high school graduates lack adequate preparation for academic writing during their first year of university education (Fitzhugh, 2006; Hotchkiss \& Hougen, 2012; Heller \& Greenleaf, 2007). Indeed, some scholars attribute such unpreparedness to the five-paragraph essay writing style that high school students learn because it is formulaic and does not expose them to mental challenges (Foley, 1989; Tremmel, 2011; Wesley, 2000).

Conversely, other scholars applaud and describe the five-paragraph essay as appropriate in preparing high school students for university because such writing style provides a starting point for students to learn how to

Dr. Ukwuoma, a literacy researcher, teaches advanced research courses for the Technical Writing and Academic Literacy (TWAL), Unit of BIUST. He can be reached at ujucukwuoma@aol.com or ukwuomac@biust.ac.bw. 
write (Perin, 2000; Seo, 2007; Smith, 2006). Incidentally, the controversy in determining if the five-paragraph essay writing style helps or hurts writing instruction has lingered unabated for years (Nunes, 2013). In spite of this controversy, little or no study has examined if first-year university undergraduates taking English language academic writing courses consider their prior knowledge of high school English language five-paragraph essay writing style helpful. Thus, the purpose of this study was to examine if first-year university undergraduates taking English language academic writing courses consider prior knowledge of high school English language five-paragraph essay writing style helpful. The following research questions guided the study: (1) Do first-year university undergraduates report that prior knowledge of high school English language five-paragraph essay writing style is helpful in university English language academic writing courses? (2) Do first-year university undergraduates who reported that prior knowledge of high school English language five-paragraph essay writing style is helpful, also report that they are level-appropriate competent in first-year university undergraduate English language academic writing courses after one academic year?

\section{Theoretical Framework}

The theoretical framework of this study is the process approach to writing (Pintrich, Smith, Garcia, \& McKeachie, 1993; Nist \& Simpson, 2000). The process paradigm is often evaluated and reevaluated by theorists, researchers, and teachers who are creating innovative approaches to drive writing instruction. Thus, advocates of process writing draw from various fields and multiple perspectives including the theories of cognitive and meta-cognitive processes. As a result, reading and writing instruction has moved from sole focus on one strategy to focusing on processes. Indeed, it is not only the actual writing that is important, prewriting activities are also important in the writing process because they contribute to the production of a particular piece of writing. At the university level, students should be taught to focus on prewriting, writing, and rewriting strategies. Specifically, writing should be viewed as a recursive rather than linear process. In other words, teachers should not reduce writing to rules and regulations because the process approach considers writing as holistic and intuitive, which is rational and sometimes non-rational.

\section{Literature Review}

Many university students around the world struggle with academic writing in such areas as research reports and discipline specific essays (Ketsitlile \& Bulawa, 2012). University students are often asked to write for the purpose of discovering what they have learned (Johnson, Smagorinsky, Thompson, \& Fry, 2003; Mutnick, 1996). As such, academic writing plays an important role for students in undergraduate programs (Noll \& Fox, 2003). First-year university undergraduates in African universities are not different from their peers around the world in being frustrated with academic writing. As such, Ukwuoma (2014b) implored teachers in universities in Africa to integrate writing and reading instruction into content areas. Ukwuoma (2014b) noted that writing is a lifelong activity because as one writes in a particular way for a given subject, one also learns about making sense of the subject. Although school subjects organize knowledge differently, it is helpful for students because they learn about those subjects as they write about them (Crème \& Lea, 2008).

Thus, university teachers and literacy professionals have important roles to play in this respect because the way a teacher delivers his or her subject matter will promote or inhibit learning. Several researchers have found that high school graduates lack the experience, skills, and knowledge of academic writing (Bizzell, 1982; Caffarella \& Barnet, 2000; Jalongo, 2002). Indeed, high school students enter universities as if they have not 
been exposed to any form of academic writing hence unable to tackle the rigors of academic writing (Fitzhugh, 2006; Hotchkiss \& Hougen, 2012; Heller \& Greenleaf, 2007). Majority of first-year university undergraduates consider writing a difficult task and often grapple with how to get started with their writing. In their study, Crème and Lea (2008) found that blank pages induce panic on students because they often do not know how to write. According to Murray and Moore (2009), many first-year university undergraduates spend lots of time reading but struggle when it comes to putting their ideas on paper. To encourage students in their writing journey, university teachers and literacy professionals should inform students that academic writing does not mean a finished written work because it includes the mistakes they make in the writing process. Accordingly, Murray and Moor (2009) described writing as "a continuous process involving reflection, improvement, development, progress and fulfillment of various types and in varying measures” (p. 5).

Lack of confidence is another reason why many university students struggle with academic writing (Crème \& Lea, 2008). To illustrate, students feel like they do not have anything to write about. Although writing can be a daunting task, there are teachable skills that will help students improve their writing so they can change their perspectives regarding academic writing. To facilitate a change in perspective, first-year university undergraduates should accept writing and reading like any other lifelong activity, which requires time to attain proficiency (Ukwuoma, 2014b). Conversely, high school teachers should vary their teaching to lay the necessary foundation for students to learn how to write in specific disciplines when they become university undergraduates. This is necessary because writing is a crucial skill used to evaluate the readiness of high school students for academic writing in different fields in the universities (Conley, 2007). On the other hand, students should accept the idea that learning how to write requires patience and dedication.

What is more worrisome, however, is that students entering university are unfamiliar with discourse communities of their disciplines. When students are unaware of the discourse communities of their disciplines, they find academic writing a challenge. Therefore, it is important for university teachers to help students learn the discourse community in their various disciplines to avoid being "locked outside the community's discourse" (Noll \& Fox, 2003, p. 332). Similarly, Bazerman (1985) emphasized that students should learn "the conversations of the discipline" (p. 10) to improve their academic writing skills. Crème and Lea (2008) identified lack of proficiency in English language as a major setback for learners of academic writing. As such, students should go back to the basics and work to understand English tenses, parts of speech, how to use the right word order and punctuation. In spite of the challenges students encounter in learning English, it is important for students to do well in the language because proper use of English improves academic performance and makes students employable in an austere world especially because English is a global language (Casale \& Posel, 2011; Chou, 1991; Crystal, 1997; Hanson, 1997; Sanmugam \& Harun, 2013).

Students also struggle with understanding the purpose of the different stages of writing such as planning, introduction, paragraph development and use of connectives, conclusion, proof-reading, and editing. It is important for students to make out time for initial planning before they embark on the actual writing. They should also consider planning, drafting, redrafting, editing, and the final write-up as part of an iterative and recursive process in writing. Furthermore, students should enjoy academic writing so it can be meaningful to them (Crème \& Lea, 2008). This is particularly important because it has been noted that "your writing can be a companion to your learning rather that an imposing enemy" (Murray \& Moore, 2009, p. 5). Working as part of a group or pair can also motivate students to see the fun in academic writing, which is rewarding and 
worthwhile. Irrespective of how difficult academic writing is, students should understand that the journey to becoming a writer is an important journey. Academic writing is a journey that leads us to "many new discoveries about ourselves, about our ideas, about the world in which we live and about our professional identities as academics, teachers, researchers and scholars" (Murray \& Moore, 2009, p. 4).

\section{Research Method}

\section{Design and Instruments}

This study was a qualitative dominant mixed research (i.e., QUAL + quan), also known as qualitatively-driven mixed research (Johnson, 2012). The inquiry applied a purposeful random sampling frame comprising of well-informed sources to ascertain the opinion of two groups of first-year university undergraduates who completed three different courses that lasted for two semesters (Kemper, Stringfield, \& Teddlie, 2003; Patton, 1987). The survey was conducted using a researcher developed Self-Report of Academic Writing Questionnaire (SRAW-Q). The SRAW-Q was hand-delivered to allow respondents indicate their preferences on closed questions and to respond to open ended questions (Bryman, 2006; Ukwuoma, 2015a). Furthermore, the participants were interviewed and their writing samples obtained for analysis to facilitate data triangulation (Leech \& Onwuegbuzie, 2008).

\section{Participants}

A total of 67 students who recently completed the following courses (1) English language for academic writing; (2) general education course in communication and academic literacy for social sciences; and (3) research and academic writing for sciences, participated in the initial survey during the first semester of 2012-2013 academic session. They also participated in the follow-up writing sample analysis and interview, which took place during the second semester of 2014-2015 school year. The participants were drawn from two regionally accredited public universities in Botswana in the southern hemisphere of Africa. The writing samples of 20 students were randomly chosen for analysis whereas the researcher engaged 15 students in qualitative interviews (i.e., "interviews that sacrifice uniformity of questions to achieve fuller development of information", Weiss, 1994, p. 3). The analyzed writing samples were discipline specific covering topics in research and the social sciences such as poverty, governance, research designs, and philosophical worldviews. The participants chosen for qualitative interview were those who indicated that they have level-appropriate competence in the first-year university undergraduate academic writing courses after one academic year.

\section{Analysis}

Responses to SRAW-Q were analyzed using simple frequency count and percentile distribution (Ukwuoma, 2015a) whereas content analysis, which is a systematic and objective procedure for analyzing written work (Elo \& Kyngas, 2008), were carried out on the essay samples. Data from the qualitative interview were transcribed verbatim and analyzed using the framework of Yin (2011), which recommends compiling, disassembling, reassembling, interpreting, and concluding. Specifically, regarding the interviews, themes emerged through constant comparison analysis (Strauss \& Corbin, 1998; Ukwuoma, 2015b). Although the respondents were a convenience sample, they were purposively selected as students of English language academic writing courses to increase credibility. As such, they constituted an "information-rich source" (Patton, 1987, p. 58; Ukwuoma, 2015b), capable of providing answers to the research questions of this study. 


\section{Results}

The purpose of this study was to examine if first-year university undergraduates taking English language academic writing courses consider prior knowledge from high school English language five-paragraph essay writing style helpful. Quantitative data from survey results showed that in 2012, all of the 67 SRAW-Q respondents reported that they are proficient in the high school five-paragraph essay writing style. After one academic session, all of the respondents indicated agreement to the idea that prior knowledge of the high school five-paragraph essay writing style facilitated a transfer of learning in the first-year university undergraduate academic writing courses. However, only 15 out of the respondents, who reported that prior knowledge of the high school English language five-paragraph essay writing style was helpful, also reported that they are level-appropriate competent in the first-year university undergraduate English language academic writing courses after one academic year. Data from the qualitative component of this study was similar to results from the quantitative data but it offered examples from writing samples and interview transcripts to corroborate findings from the quantitative data.

Some observations from the writing sample are noted as follows:

(1) Planning: In some of the writing samples, participants did not seem to have thought of planning their writing or using outlines. Most of them did not engage in any pre-writing activity. Specifically, the students appear unaware of pre-writing strategies such as brainstorming, clustering, free writing, and mind mapping. They just plunged into the actual writing. Those who appeared to have planned their writing limited their works to five-paragraphs even when their sentences indicated that they had more to write about; (2) Introduction: Some of the participants did not give their readers a clear path or structure to follow in their essays. The length of introductory sections of some of the reviewed writing samples were more than one and half pages in a threepage long essay; (3) Paragraph development: Most of the writing samples did not show clear linkage from the introductory paragraphs to other parts of the work. Some of the written work had too many ideas clustered in one paragraph; (4) Reference: Some of the participants who presented definitions failed to acknowledge their sources; and (5) Conclusions: Although most students did well in dedicating their last paragraphs to conclusions, they did not link their conclusions to the introduction as a way of engaging the reader.

\section{Discussion}

During the interview, participants indicated that they are aware of the purpose of an introduction in discipline specific essay as well as the need to link it to the conclusion yet did not do that. According to one student, "I did not consider it important because I thought the essay only wanted me to define and explain". It is important to point out that an introduction is necessary to give the reader a window to the rest of the work. The absence of an introduction breeds incoherence and makes readers wonder what will come next. Other students acknowledged that they "try everything possible to limit their essays to five-paragraphs". As a result of such misunderstanding, easy flow of reading is disturbed including the understanding of ideas and concepts. Some of the participants also forgot to make clear linkage from one paragraph to the other, which means that ideas did not flow in logical sequence in most of the essays. Some students failed to conclude their essays. As with the introduction, some students had no idea of the function or purpose of a conclusion in a text or how to draw a conclusion in an academic essay. Even when some students concluded their essays properly, it was difficult to get the main ideas because they often have unclear sequence and ideas that are not clearly supported and argued. 
Most of the essays were not focused on the assigned topics. In other words, some students submitted irrelevant materials. A handful of students wrote compelling essays yet they describe academic writing as frustrating,

I find academic writing frustrating because writing in university is very different from the high school writing, in secondary school we were allowed to be creative as much as we want, with academic writing, even if one tries his best to write well, he will be told that he did not put enough effort in their writing.

Some of the students described academic writing as boring, "academic writing is boring because there is no fun in it. We are told what to do. Maybe the lecturers need to make it more enjoyable for the students". It is important to point out that if teachers of writing allow students to own and sometimes, determine what they write, the perception that writing is boring may be reduced among students (Flint \& Cappello, 2003). Most of the students also pointed out that academic writing is formulaic like the five-paragraph essay particularly when it comes to referencing.

\section{Implications and Conclusion}

Only a few of the students who participated in this study can be said to have level-appropriate competence or some proficiency in first-year university undergraduate academic writing courses. The knowledge of high school five-paragraph essay writing style somehow facilitated a transfer of learning in university level academic writing courses. Yet, freshmen acknowledge that they struggle more with English language academic writing courses than they did during high school. Although universities have higher academic expectations from their students than high schools, it is clear from this study that students lack experience, skill, and knowledge of academic writing, which is essential to excel in university education. As such, there is need for a bridge course for students entering university. This course will highlight the basics of academic writing and the different discourse communities for different disciplines in universities. In addition, this course will be an ideal way to engage students as writers and arouse their interest, curiosity, and love for academic writing. Furthermore, policy makers should ensure that university campuses are equipped with functional Writing Centers to scaffold students learning. Writing teachers in the university should work collaboratively with language teachers. On the other hand, students should form and be part of writing groups to assist one another with their writing. Most importantly, the controversy bordering on whether high school essay writing style hurts or helps students in academic writing is unnecessary. On the whole, if high school academic writing is properly articulated, it can prepare students with the necessary foundational knowledge to succeed in academic writing in universities and professional communications outside of schools.

\section{References}

Aina, J. K., Alexander, G. O., \& Shola, S. O. (2013). Students' proficiency in English language: Relationship with academic performance in science and technical education. American Journal of Educational Research, 1(9), 355-358.

Bazerman, C. (1985). Physicist reading physics: Schema-laden purposes and purpose-laden schema. Written Communication, 2 , 3-23.

Bizzell, P. (1982). College composition: Initiation into the discourse community. Curriculum Inquiry, 12, 191-207.

Blaxter, L., Hughes, C., \& Tight, M. (1998). Writing on academic careers. Studies in Higher Education, 23(3), $282-295$.

Bryman, A. (2006). Integrating quantitative and qualitative research: How is it done? Qualitative Research, 6(1), 97-113.

Caffarella, R. S., \& Barnet, B. G. (2000). Teaching doctoral students to become scholarly writers: The importance of giving and receiving critiques. Studies in Higher Education, 25, 39-52. 
Casale, D., \& Posel, D. (2011). English language proficiency and earnings in a developing country: The case of South Africa. Journal of Socioeconomics, 40, 385-393.

Chilisa, B., \& Preece, J. (2005). Research methods for adult educators in Africa. Cape Town: Pearson Educational South Africa.

Chou, C. T. (1991). A study on the effect of early start in learning English as reflected in children's later English competence. English Teaching and Learning, 15, 45-54.

Chovance, J. (2012). Written academic discourse in English: From local traditions to global outreach. Brno Studies in English, $38(2), 5-16$.

Conley, D. T. (2007). Redefining college readiness. Eugene, OR: Educational Policy Improvement Centre.

Cramarenco, R. E., Moraru, C., Balazsi, R., \& Aluas, M. (2015). Meta-analysis versus systematic review in studies regarding specific interventions in academic writing in English. Cognition, Brain, Behavior: An Interdisciplinary Journal, XIX(1), 55-73.

Crème, P., \& Lea, M. (2008). Writing at university. Berkshire: Open University Press.

Crystal, D. (1997). English as a global language. Cambridge UK: Cambridge University Press.

Curry, M. J., \& Hewings, A. (2003). Approaches to teaching writing. In C. Coffin, M. J. Curry, S. Goodman, A. Hewings, T. M. Lillis, and J. Swann (Eds.), Teaching academic writing: A toolkit for higher education. London, United Kingdom: Routledge.

Elo, S., \& Kyngas, H. (2008). The qualitative content analysis process. Journal of Advanced Nursing, 62(1), 107-115.

Fitzhugh, W. (2006). Where's the "content”? Educational Leadership, 64(2), 42-46.

Flint, A. S., \& Capello, M. (2003). Negotiating voice and identity in classroom writing events. In C. M. Fairbanks, J. Worthy, B. Maloch, J. V. Hoffman, and D. L. Schallert (Eds.), 52nd yearbook of the national reading conference (pp. 181-193). Oak Creek: NRC.

Foley, M. (1989). Unteaching the five paragraph essay. Teaching English in the Two-Year College, 16(4), 231-235.

Hanson, J. (1997). The mother of all tongues: Review of David Crystal's English as a global language. Times Higher Education Supplement, 12(88), 22.

Heller, R., \& Greenleaf, C. L. (2007). Literacy instruction in the content areas: Getting to the core of middle and high school improvement. Washington, DC: Alliance for Excellent Education.

Hotchkiss, K., \& Hougen, M. (2012). Writing like a historian: What teacher candidates should know and be able to teach. The Social Studies, 103, 149-157.

Jalongo, M. R. (2002). Writing for publication: A practical guide for educators. Norwood, MA: Christopher Gordon.

Johnson, B., \& Christensen, L. (2012). Educational research: Quantitative, qualitative and mixed approaches (4th ed.). Los Angeles, CA: Sage.

Johnson, T. S., Smagorinsky, P., Thompson, L., \& Fry, P. G. (2003). Learning to teach the five-paragraph theme. Research in the teaching of English, 38(2), 1399-1436.

Jabulani, S. (2014). An analysis of the language of attribution in university students' academic essays. South African Journal of Education, 34(3), 1-10.

Kemper, E. A., Stringfield, S., \& Teddlie, C. (2003). Mixed methods sampling strategies in social science research. In A. Tashakkori and C. Teddlie (Eds.), Handbook of mixed methods in social and behavioral research (pp. 273-296). Thousand Oaks, CA: Sage.

Kern, R., \& Schultz, J. M. (2005). Beyond orality: Investigating literacy and the literary in second and foreign language instruction. The Modern Language Journal, 89(3), 381-392.

Ketsitlile, L. E., \& Bulawa, P. (2012). A Summary test: Criterion for majoring in the English language and literature at the University of Botswana. NAWA: Journal of Language and Communication, 6(2).

Leech, N. L., \& Onwuegbuzie, A. J. (2008). Qualitative data analysis: A compendium of techniques for school psychology research and beyond. School Psychology Quarterly, 23, 587-604.

Moje, E. B. (2008). Foregrounding the disciplines in secondary literacy teaching and learning: A call for change. Journal of Adolescent and Adult Literacy, 52(2), 96-107.

Munoz-Luna, R. (2013). From drills to CLIL: The paradigmatic and methodological evolution towards the integration of content and foreign language. Profile Journal, 16(1), 167-180.

Murray, R., \& Moore, S. (2009). The handbook of academic writing: A fresh approach. Berkshire: Open University.

Mutnick, D. (1996). Writing in an alien world: Basic writing and the struggle for equality in higher education. Portsmouth: Boynton/Cook. 
Nelson, N., \& Calfee, R. (1998). The reading-writing connection viewed historically. In N. Nelson and R. Calfee (Eds.), The reading-writing connection (pp. 1-52). Chicago: NSSE.

Nist, S. L., \& Simpson, M. L. (2000). College studying. In M. L. Kamil, P. Mosenthal, P. D. Pearson, and R. Barr (Eds), Handbook of reading research (Vol. 3). New Jersey: LEA.

Noll, E., \& Fox, D. L. (2003). Supporting beginning writers of research: Mentoring graduate students entry into academic discourse communities. In C. M. Fairbanks, J. Worthy, B. Maloch, J. V. Hoffman, and D. L. Schallert (Eds.), 52nd yearbook of the national reading conference (pp. 332-344). Oak Creek: NRC.

Nunes, M. J. (2013). The five-paragraph essay: Its evolution and roots in theme-writing. Rhetoric Review, 32(3), 295-313.

Patton, M. Q. (1987). Qualitative research and evaluation methods (3rd ed.). Thousand Oaks, CA: Sage.

Perin, R. (2000). 10:00 and 2:00: A ten-paragraph defense of the five-paragraph theme. Teaching English in the Two-Year College, 27(3), 312-314.

Pintrich, P. R., Smith, D. A., Garcia, T., \& McKeachie, W. J. (1993). Reliability and predictive Validity of the Motivation Strategies for Learning Questionnaire (VMSLQ). Educational and Psychological Measurement, 53, 801-813.

Poel, K., \& Gasiorek, J. (2012). Effects of an efficacy focused approach to academic writing on students' perceptions of themselves as writers. Journal of English for English for Academic Purposes, 11(4), 294-303.

Sanmugam, S. T., \& Harun, R. N. (2013). Technical instructions in English: Voices of technical lecturers. Journal of Technical Education Training, 5(1), 1-3.

Seo, B. (2007). Defending the five paragraph essay. English Journal, 97(2), 15-16.

Smith, K. (2006). In defense of the five paragraph essay. English Journal, 95(4), 16-17.

Strauss, A., \& Corbin, J. (1998). Basics of qualitative research: Techniques and procedures for developing grounded theory. Thousand Oaks, CA: Sage.

Tremmel, M. (2011). What to make of the five paragraph theme: History of the genre and implications. Teaching English in the Two-Year College, 39(1), 29-42.

Ukwuoma, C. U. (2014a). College lecturer's perspectives on the role of Nigerian Creole in teacher education. Retrieved from http://gradworks.umi.com/35/80/3580948.html

Ukwuoma, U. C. (2014b). Reflections on a reading clinic at one university: Roles and responsibilities. NAWA: Journal of Language and Communication (NJLC), 8(2), 106-118.

Ukwuoma, U. C. (2015a). Mixed research: Exploring postgraduate students perspectives. International Journal of Novel Research in Education and Learning, 2(4), 135-141.

Ukwuoma, U. C. (2015b). Nigerian Creole as language of instruction: Will Nigerian lecturers use Nigerian Creole? Reading \& Writing, 6(1), 75, 1-8.

Walker, G. E., Golde, C. M., Jones, L., Conklin Bueschel, A., \& Hutchings, P. (2008). The formation of scholars: Rethinking doctoral education for the twenty-first century. San Francisco: Jossey-Bass.

Weiss, R. S. (1994). Learning from strangers: The art and method of qualitative interview studies. New York. NY: The Free Press.

Wesley, K. (2000). The ill effects of the five paragraph theme. English Journal, 90(1), 57-60.

Yin, R. K. (2011). Qualitative research from start to finish. New York, NY: Guilford. 